\title{
Telephone-based peer support increased the duration of breast feeding in primiparous mothers
}

Sources of funding:

University of Toronto

Faculty of Nursing;

Maternal, Infant, and

Reproductive Health

Research Unit.

For correspondence:

Dr C L Dennis,

University of Toronto

Toronto, Ontario

Canada.

cindylee.dennis@

utoronto.ca.

A modified version of

this abstract also

appears in

Evidence-Based

Nursing.

Peer support $v$ conventional care for breastfeeding primiparous motherst

\begin{tabular}{lllll} 
Outcomes & $\begin{array}{l}\text { Peer } \\
\text { support }\end{array}$ & $\begin{array}{l}\text { Conventional } \\
\text { care }\end{array}$ & RBI (95\% Cl) & NNT (Cl) \\
$\begin{array}{c}\text { Breast feeding at } 4 \\
\text { weeks } \neq\end{array}$ & $92 \%$ & $84 \%$ & $11 \%(1$ to 16$)$ & 12 (8 to 191$)$ \\
\hline $\begin{array}{c}\text { Breast feeding at } 8 \\
\text { weeks } \ddagger\end{array}$ & $85 \%$ & $75 \%$ & $17 \%(3$ to 25$)$ & 8 (6 to 40$)$ \\
\hline $\begin{array}{c}\text { Breast feeding at } 12 \\
\text { weeks } \neq\end{array}$ & $81 \%$ & $67 \%$ & $25 \%(9$ to 35$)$ & $6(5$ to 17$)$ \\
\hline $\begin{array}{c}\text { Exclusive breast } \\
\text { feeding at } 12 \\
\text { weeks }\end{array}$ & $57 \%$ & $40 \%$ & $41 \%(9$ to 84$)$ & 7 (4 to 24$)$ \\
\hline
\end{tabular}

†Abbreviations defined in glossary; RBI, NNT, and $\mathrm{Cl}$ calculated from data in article.

‡Based on adjusted analysis.

\section{COMMENTARY}

Breast feeding is known to reduce the incidence of infections and allergies and improve nutritional status and neurodevelopment in infants. ${ }^{1-3}$ Although many mothers initiate breast feeding, many stop in the first 6 weeks postpartum. The study by Dennis $e t$ al was done in a semiurban setting. $75 \%$ of the mothers were college or university educated. It is uncertain, therefore, if these results could be reproduced among low income women, who typically have low rates of breast feeding. ${ }^{4}$ More women in the intervention group than in the control group had decided to breast feed antenatally, which is known to increase the likelihood of successful breast feeding, ${ }^{4}$ possibly confounding the results.

Breast feeding is widely promoted. The effectiveness of large initiatives, however, has seldom been rigorously evaluated. Most studies have assessed professional rather than peer support.

The results provide evidence that a simple and inexpensive telephone-based peer support programme can increase the duration of breast feeding among well educated women. Such programmes could be readily established in collaboration with existing volunteer breast feeding support groups. Further study is needed to determine whether the intervention would be successful among poor mothers, who are less likely to start and sustain breast feeding.

Karen Simmer, MBBS King Edward Memorial Hospital for Women and Princess Margaret Hospital for Children Subiaco, Western Australia, Australia

1 Lucas A, Brooke OG, Morley R, et al. Early diet of preterm infants and development of allergic or atopic disease: randomised prospective study. BMJ 1990;300:837-40.

Lucas A, Morley R, Cole TJ, et al. Breast milk and subsequent intelligence quotient in children born preterm. Lancet 1992;339:261-4.

Hylander MA, Strobino DM, Dhanireddy R. Human milk feedings and infection among very low birth weight infants. Pediatrics 1998;102:e38.

Scott JA, Aitken I, Binns CW, et al. Factors associated with the duration of breastfeeding amongst women in Perth, Australia. Acta Paediatr 1999;88:416-21.
Patients

258 in-hospital, primiparous, breastfeeding women who were $\geq 16$ years of age, were able to speak English, had a singleton birth at $\geq 37$ weeks of gestation, and were accessible by a local telephone call. Exclusion criteria were factors that could seriously interfere with breast feeding (eg, serious maternal illness or infant congenital abnormality) or prenatal enrolment with the participating volunteer breast feeding organisation. 256 women (99\%) completed the trial and were included in the analysis. Most $(75 \%)$ were between 25 and 34 years of age.

\section{Intervention}

132 women were allocated to the peer-support group, which included telephone-based peer support plus conventional in-hospital and community postpartum services (eg, a hospital-based breast feeding clinic and support services by public health nurses). Each new mother was paired with a peer volunteer (ie, a mother who had $\geq 6$ mo of previous breastfeeding experience and a positive attitude towards breast feeding and had completed a $2.5 \mathrm{~h}$ orientation session) who lived nearby and was readily available. Peer volunteers were asked to contact the new mother within 48 hours after hospital discharge and as frequently thereafter as the mother deemed necessary. 126 women were allocated to conventional care only.

\section{Main outcome measure}

Main outcome was self reported breast feeding (receipt by the infant of any breast milk) in the 24 hours before the interview.

Main results

Analysis was by intention to treat. Mothers who received peer support were more likely to be breast feeding at 4,8 , and 12 weeks postpartum than were mothers who received conventional care only (table). Furthermore, mothers in the peer-support group were more likely to be breast feeding exclusively at 12 weeks (table).

\section{Conclusion}

Primiparous, breastfeeding mothers who received telephone-based peer support were more likely to still be breast feeding at 12 weeks postpartum than were mothers who received conventional care alone.

*See glossary. 